\title{
Could the Plume of Tuxpan River Influence the Norther Reefs of the Reef Corridor of The Southwestern Gulf of Mexico?
}

\author{
Fernando Rodríguez Lehovec ${ }^{1}$, José de Jesús Salas Pérez ${ }^{2 *}$, Guillermo Jordán Garza² and David Salas Monreal² \\ ${ }^{1}$ División Académica de Ciencias Básicas, Universidad Juárez Autónoma de Tabasco, México
}

${ }^{2}$ Universidad Veracruzana, México

Submission: February 06, 2021; Published: March 24, 2021

Corresponding author: José de Jesús Salas Pérez, Universidad Veracruzana, Lomas del Estadio s/n, Xalapa-Veracruz, México, CP 91000

\begin{abstract}
For 2005 summer season, the period of maximum rain, surface satellite data: Sea Surface Temperature and geostrophic currents measured with the altimeter radar were used to show the Tuxpan river plume influence over the Tuxpan reef matrix. The analysis showed Tuxpan river plume influence over Tuxpan reef matrix when it has shapes, like a crest form, a bell shape.
\end{abstract}

Keywords: Tuxpan river plume; Shape of the plume; Tuxpan reef matrix; Sea surface temperature; Geostrophic currents

\section{Introduction}

River discharges are strongly influenced by rainfall, which, when increasing, is directly proportional to the expenses of the rivers, which are direct fertilizers for the sea [1]. The Tuxpan river is located in the northern coastal area of the state of Veracruz and is located $10 \mathrm{~km}$ from the Tuxpan reef and $15 \mathrm{~km}$ from the Enmedio and Tanhujio reefs, which are part of the Lobos-Tuxpan (LT) reef matrix located in the north part of the southwestern reef corridor from the Gulf of Mexico [2,3] (Figure 1). The study area is irrigated by the Common Gulf of México Water (CGMW) recirculated by a diurnal tide and dominated by a mesoscale and wind induced circulation [3-5]. It has been a matter of debate by specialists in the study of corals, whether the plume of the Tuxpan river affect the Tuxpan's reefs with sandy and mud type sediments which had been found there (Jordán-Garza, personal communication).

River Tuxpan have a summer discharge associated to the rainfall season $>139 \mathrm{~m}^{3} / \mathrm{s}$, which is greater than the Jamapa and Coatzacoalcos rivers, located in front of the Parque Nacional Sistema Arrecifal Veracruzano (PNSAV) and los Tuxtlas reefs (TR), respectively [6,7]. The rain in the year of 2005 in the reef corridor of the southwestern Gulf of Mexico 2005, was higher than in 24 hrs. than the general reported average monthly accumulation rain in the study area, inducing strong river discharges of the most im portant rivers (Tuxpan, Jamapa and Coatzacoalcos rivers) of the coastal zone of the Veracruz state [3,6-8]. There aren't previous studies which focuses to study the Tuxpan plume River and its influence over the reefs, so in this study, satellite data will be used to study the plume of the Tuxpan River: sea surface temperature, extension, and geometry and its influence on the reef system of the same name (Figure 1).

\section{Results}

\section{Rainfall}

The rains originate from the arrival of tropical air masses to this region, as well as from the interaction with the orography, their season occurs in summer, a season dominated by the passage of tropical atmospheric systems in the Gulf of Mexico and in the South Pacific, mainly in the Gulf of Tehuantepec. Tropical cyclones are frequent in the rainy season until reaching their maximum in September, before descending to minimum values in November $[7,8]$. The study was doing on summer of 2005 , the rainy season, which was a year of maximum rainfall $(117 \mathrm{~mm}-357 \mathrm{~mm})$ in the reef corridor of the southwestern Gulf of Mexico. So, the rainfall analysis in this study focuses only in those days of maximum rain, which guaranties days of maximum river discharge of the Tuxpan 
river in the study area (Figure 1), and of course a major river waters influence on Lobos-Tuxpan coral reef matrix. In June of 2005 there were four days of maximum rain, the values of the rain lesser than to $30 \mathrm{~mm} /$ day take place on days 15 and 22 .

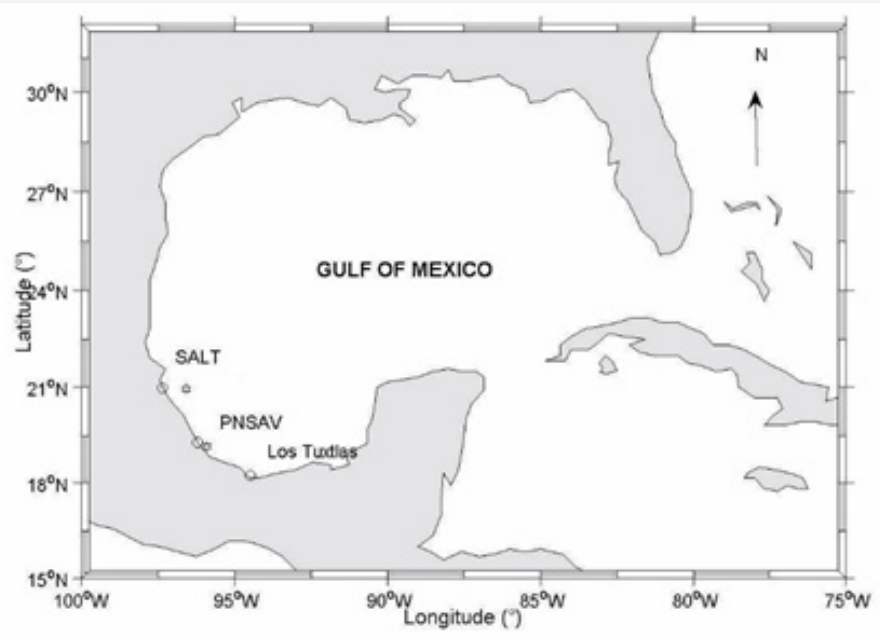

Figure 1: Reef corridor of the southwestern Gulf of Mexico. There are observed the three major reef system in the reef corridor: To the north, Sistema Arrecifal Lobos-Tuxpan (SALT), Parque Nacional Sistema Arrecifal Veracruzano (PNSAV), middle part of the corridor, and to the south Los Tuxtlas reefs.

\section{SST images}

Sea Surface Temperature of June 15 of 2005 , with values between $28.5^{\circ} \mathrm{C}$ and $28.6^{\circ} \mathrm{C}$, showed the Tuxpan river plume elongated to the north, irrigating the coral reefs of Tanhuijo and En medio, the Tuxpan reef there was not influenced by Tuxpan river discharge, the surface geostrophic currents observed with altimeter satellite had a predominant westward direction (Figure 2). On June 22, the surface current remains with the westward direction and the river Tuxpan plume had an extension to the east, with SST values of $28.92^{\circ} \mathrm{C}$ and $28.93^{\circ} \mathrm{C}$, without an influence of its waters on Tanhuijo reef (Figure 3).

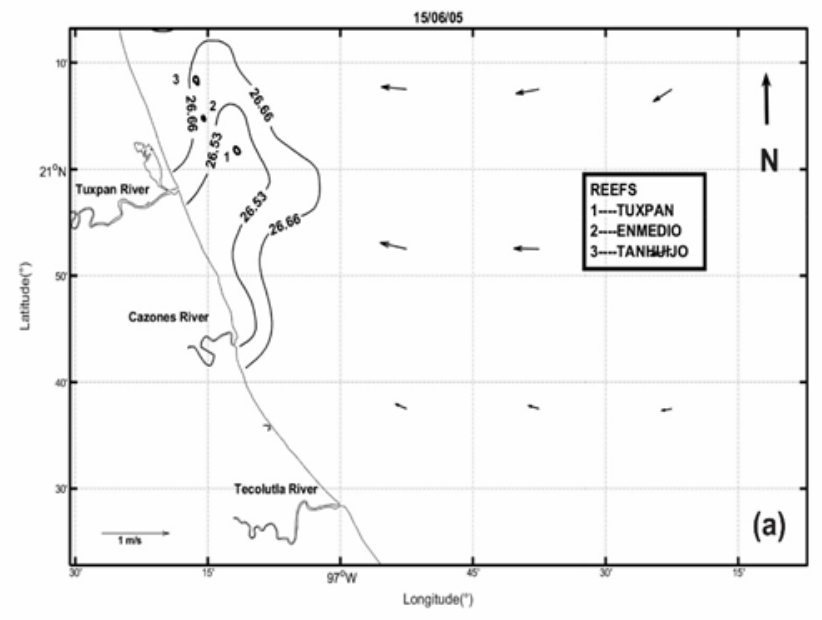

Figure 2: Sea Surface Temperature contour of the Tuxpan River plume plus geostrophic currents for 15 of June of 2005. The numbers indicate the Tuxpan reefs matrix: 1) Tuxpan reef, 2) En Medio reef, 3) Tanhuijo reef.

\section{Discussion}

The coastal zone of the study area is irrigated by the Common Gulf of Mexico Water (CGMW) which have mean values of tem- perature and salinity of $26^{\circ} \mathrm{C}$ and 36.5 ups [4]. The river plume of the Tuxpan River influences with its discharges the coastal CGMW, increasing the water temperature and reducing the salinity values 
[3]. Moreover, rivers plumes, around the world coastal zones, introducing to the sea sediments, mainly sandy and mud type [1]. Coral reefs of the world, to maintaining healthy must have marine waters without sediments [2]. However, the reef corridor of the southwestern Gulf of Mexico, is highly influenced by river discharges, with high content of sandy and mud type [6], particularly the reefs in front of the Parque Nacional Sistema Arrecifal Veracruzano (PNSAV) and los Tuxtlas reefs, both located at the middle and the south of the study area, respectively. They suffered the influence of the Jamapa and Coatzacoalcos Rivers by their proximity of the reefs in those study areas $[1,3,6]$.

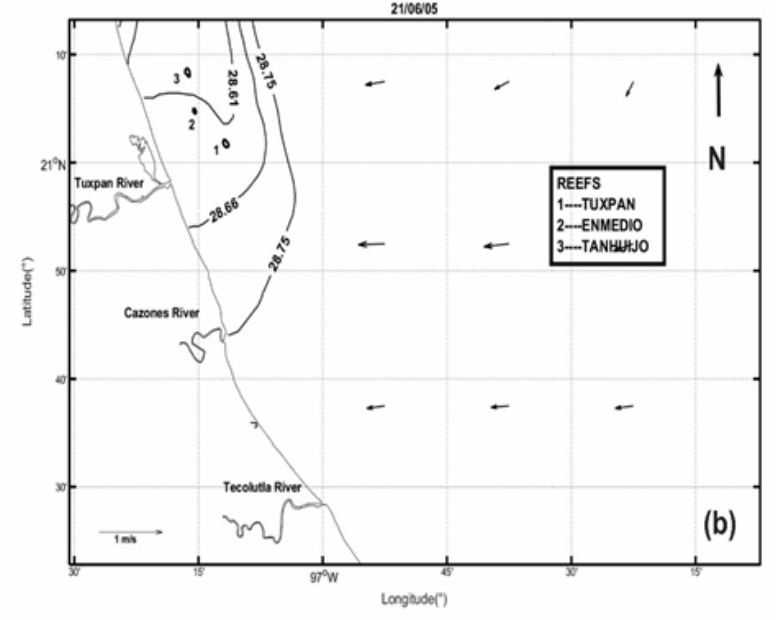

Figure 3: Sea Surface Temperature contour of the Tuxpan River plume plus geostrophic currents for 22 of June of 2005. The numbers indicate the Tuxpan reefs matrix: 1) Tuxpan reef, 2) En Medio reef, 3) Tanhuijo reef.

However, the Lobos-Tuxpan reef matrix, until this study has been in debate by the distance, 10 to $15 \mathrm{~km}$ of the Tuxpan River plume to the reef matrix [3]. Our analysis showed the influence of the water discharge of the River Tuxpan plume over the reefs, only in summer season, which is the period of rain, at this period the maximum year (2005) of rain in the reef corridor of the southwestern Gulf of Mexico [8], with a rainfall interval of $25 \mathrm{~mm} /$ day to more than $120 \mathrm{~mm} /$ day, associated with a river Tuxpan discharge $>139 \mathrm{~m}^{3} / \mathrm{s}$. The results analyzed previously, showed that surface mesoscale currents when going from the open sea to the mouth of the river, there could be more influence of it in the Tuxpan reef matrix. The river Tuxpan plume have impact with its water, with shapes: concave and in a form of a crest wave.

\section{Conclusion}

The surface satellite data (SST and geostrophic currents), analyzed in this study, showed that the Tuxpan river plume, has influence over the Tuxpan matrix in summer season, the period of maximum rain. The Tuxpan river plume influenced the Tuxpan reef matrix when it has shapes, like a concave form, and in a form of a crest wave.

\section{References}

1. Salas-Monreal, David, Riveron-Enzastiga, Mayra Lorena; José de Jesus Salas-Perez, et al. (2020) Bathymetric flow rectification in a tropical micro-tidal estuary. Estuarine, Coastal and Shelf Science 235: 106562.
2. Jordán-Garza AG, González-Gándara C, Salas-Pérez JJ, Morales-Barragán AM (2017) Coral assemblages are structured along a turbidity gradient on the Southwestern Gulf of Mexico, Veracruz. Continental Shelf Research 138: 32-40.

3. Salas-Pérez, Jose de Jesús, and Jordán-Garza AG (2018) Oceanography of the reef corridor of the southwestern Gulf of Mexico. In: Nova Science Publishers, USA.

4. Salas-Pérez, José de Jesús, Virgilio Arenas-Fuentes (2011) Water mass of Veracruz reef system. Atmósfera 24: 221-231.

5. Salas-Pérez, José de Jesús, Salas-Monreal David, Monreal-Gómez María Adela, Riveron-Enzástiga, et al. (2012) Seasonal Absolute Acoustic Intensity, Atmospheric Forcing and Currents in a Tropical Coral Reef System. Estuarine Coastal and Shelf Science 100: 102-112.

6. Salas-Pérez, José de Jesús, Ocaña-Valencia Angel Norberto, Carlos González Gandara (2015) Temperatura superficial del mar y concentración de Clorofila-a en zonas arrecifales y desembocadura de sus ríos en el golfo de México occidental. In: Alejandro Granados-Barba, Leonardo Ortiz-Lozano, David Salas-Monreal, Carlos González Gándara (Eds.), Aportes al conocimiento del Sistema Arrecifal Veracruzano: hacia el Corredor Arrecifal del Suroeste del Golfo de México, EPOMEX, México, Pp. 297-314.

7. Salas-Pérez J D J, Jordán-Garza A G, Salas-Monreal D (2020) Climate variability over the reef corridor of the southwestern Gulf of Mexico. Atmósfera 33(2): 143-157.

8. Tejeda-Martinez A, Welsh-Rodriguez C (2006) Inundaciones 2005 en el estado de Veracruz. Universidad Veracruzana, Xalapa, Veracruz, México. 

(C) This work is licensed under Creative

DOI: 10.19080/OFOAJ.2021.13.555862

\section{Your next submission with Juniper Publishers} will reach you the below assets

- Quality Editorial service

- Swift Peer Review

- Reprints availability

- E-prints Service

- Manuscript Podcast for convenient understanding

- Global attainment for your research

- Manuscript accessibility in different formats ( Pdf, E-pub, Full Text, Audio)

- Unceasing customer service

Track the below URL for one-step submission https://juniperpublishers.com/online-submission.php 